\title{
Effective methods of teaching listening to the students of higher education
}

\section{Shakhzoda FAYZULLAYEVA ${ }^{1}$}

Samarkand State Institute of Foreign Languages

\begin{tabular}{l} 
ARTICLE INFO \\
\hline Article history: \\
Received April 2021 \\
Received in revised form \\
20 April 2021 \\
Accepted 15 May 2021 \\
Available online \\
25 June 2021 \\
\hline Keywords: \\
listening, \\
foreign language, \\
audio texts, \\
higher education, \\
listening skills, \\
real-life situations, \\
difficulties, \\
problems, \\
auditing organization.
\end{tabular}

\begin{abstract}
In response to the increasing demand of learners for English as a language of international communication, issues related to the teaching of foreign language in higher education are being discussed. Effective forms and methods of teaching Englishlanguage auditing to students in higher education are being considered. The nature and role of the auditing process is noted. Audio texts that reflect real-life situations are described. Series selected and analyzed. The problems and difficulties encountered by students in learning to audit. Measures are recommended for the correct organization of the audition process in the classroom, the most effective approaches to developing the student's confidence in listening to audio texts and the ability to understand foreign language speech.

2181-1415/@ 2021 in Science LLC.

This is an open access article under the Attribution 4.0 International (CC BY 4.0) license (https://creativecommons.org/licenses/by/4.0/deed.ru)
\end{abstract}

\section{Oliy o'quv yurtlari talabalarini tinglashga o'rgatishning samarali usullari}

\author{
Kalit so'zlar: \\ tinglab tushunish, \\ chet tili, \\ audio matnlar, \\ oliy ma'lumot, \\ tinglash qobiliyatlari, hayotiy \\ misollar, \\ tinglab tushunishdagi \\ qiyinchiliklar, \\ muammolar, \\ auditorlik tashkiloti.
}

\begin{abstract}
ANNOTATSIYA
Xalqaro muloqot tili sifatida ingliz tiliga talablarning tobora ortib borayotgan talabiga javoban, oliy o'quv yurtlarida chet tilini o'qitish bilan bog'liq masalalar muhokama qilinmoqda. Oliy o'quv yurtlarida talabalarga ingliz tilida eshitish qobiliyatini shakllantirishning samarali shakllari va usullari ko'rib chiqilmoqda. Ushbu maqolada eshitish jarayonining mohiyati va roli qayd etilgan. Hayotiy vaziyatlarni aks ettiruvchi audio matnlar tasvirlangan. Seriyalar tanlangan va tahlil qilingan.

Tinglab tushunishni o'rganishda talabalar duch keladigan muammolar va qiyinchiliklar. Sinfda tinglash jarayonini to'g'ri tashkil etish, talabaning audio matnlarni tinglashda ishonchini va chet tilidagi nutqni anglash qobiliyatini rivojlantirish bo'yicha eng samarali yondashuvlar bo'yicha choralar tavsiya etiladi.
\end{abstract}

\footnotetext{
${ }^{1}$ Lecturer of the Department of Theory and Practice of Translation, Samarkand State Institute of Foreign Languages, Samarkand, Uzbekistan.
} 


\section{Эффективные методики обучения аудированию студентов высших учебных заведений}

\author{
Ключевые слова: \\ аудирование, \\ иностранный язык, \\ аудиотексты, \\ высшее образование, \\ навыки аудирования, \\ жизненные ситуации, \\ трудности, \\ проблемы, аудиторская \\ организация.
}

\begin{abstract}
АННОТАЦИЯ
В ответ на растущую потребность учащихся английскому языку как языку международного общения, обсуждаются вопросы, связанные с преподаванием иностранного языка в высших учебных заведениях. Рассмотрены эффективные формы и методы обучения англоязычному аудиту студентов высших учебных заведений. Отмечается характер и роль процесса аудита. Описываются аудиотексты, отражающие реальные жизненные ситуации. Серии отобраны и проанализированы.

Проблемы и трудности, с которыми сталкиваются студенты при обучении аудиту. Рекомендуются меры для правильной организации процесса прослушивания в классе, наиболее эффективные подходы к развитию у учащегося уверенности при прослушивании аудиотекстов и способности понимать иностранную речь.
\end{abstract}

Listening is the key to all effective communication. Without the ability to listen effectively, messages are easily misunderstood. As a result, communication breaks down and the sender of the message can easily become frustrated or irritated. If there is one communication skill you should aim to master, then listening is it.

Listening is a complex process for teaching and learning, because during listening mental processes such as auditory perception and recognition; attention; probabilistic prediction; guesswork; segmenting speech flow; informative analysis; final synthesis, assuming various compressions and interpretations of the received message $[2,34]$.

In one of his recent publications, M. Growth has described that is a necessary speech activity because it provides the listener with information. Without understanding the information no study can begin $[3,22]$.

Because of this complexity of the listening process, learners have many difficulties in understanding the language of their speakers. Difficulties cause feelings of uncertainty and even fear $[4,15]$. The task of the teacher is to solve these difficulties and to develop the ability to understand foreign language. In fact, the purpose of listening in the classroom is to enable students to navigate through certain real-life situations. If so, two very important interrelated issues are worth considering:

The characteristics of real-life situations;

How to correctly organize listening in general and in life situations in particular, taking into account their specific characteristics.

To address these issues, it is necessary to identify a range of typical situations in which some people listen to others. This, of course, will include situations where not only the process of the hearing is involved, but also other speech activities, 
usually speaking. But the main thing remains that a person needs to be able to understand what they are being told and to respond adequately to that speech [12].

The list of typical situations can be presented as follows: interviews, instructions of various kinds, loudspeakers, radio news, theatrical spectacle, telephone conversations, TV shows, in the shop, etc. It is important to note here that most of these situations the following characteristics combine:

Informal speech, which in turn has specific characteristics causing difficulties for students, such as:

- Short. It is usually split into short pieces. Conversations are rotated by short phrases;

- Pronunciation. Some words are often swallowed they differ markedly from the phonological representation of them in the dictionary. For example, can't for cannot, orright' for all right', or Sh' we go? 'for shall we go? ';

- grammar. Informal speech tends to use ungrammatical structures: statements are not clearly divided into sentences, unfinished sentences;

- Noise. Words are uttered indistinctly or not known to the listener, or attention is dissipated by outside noise;

- redundancy. Usually the speaker uses more words in his speech than is necessary to transmit the message. Excesses include the following: word repetition, corrections, speech fillers such as I mean, well, okey, etc.

How do we deal with the problem? Firstly, students should be made aware of these features, always paying attention when listening to audio texts. Now students have great opportunities to access foreign literature via the Internet. In order to work independently in the framework of project work, it is possible to give tasks on identification of features of informal speech, keeping correspondence with a native speaker, viewing a film or listening to songs. Such assignments are of much greater interest to students than the audio texts in the textbook;

1) Wait, purpose (expectation and purpose) - the listener almost always knows in advance who he's with will talk or what to talk about.

He usually has a purpose, such as to find out something, and expects to hear the information he needs.

It is therefore imperative that students have a sense of the nature of the text before listening to it. For example, the usual instruction of the teacher (which we often see in classes) "Listen to this passage" will be far less useful than the phrase "Now you will listen to the text about how the husband and wife discuss their plans about the upcoming summer holiday". This attitude of the students will be more effective because it will activate their own knowledge (scripts):

There are some events, pictures, episodes related to the summer holiday. Based on this experience, students build their own waiting, predicting events that will help them to understand the text offered for listening.

The purpose of the audition should also be clearly stated. For example, instead of saying, "Listen and try to understand..." Listen and find out where the family is He is on summer vacation. Mark the route on the map". Setting an accurate target will enable listeners to hear specific important information more easily and more naturally than to understand the entire text [12];

2) Visual contact with speaker (looking as well as listening). Rarely does the perception process take place in a blind way, such as listening to the radio or talking on the phone. The listener usually has in front of him the subject or object 
related to the subject matter of the conversation. In the first case it can be one person or group of people, in the second it can be a map, a stage, an environment etc.;

3) Timely, targeted response (ongoing, purposeful listener response). As the conversation progresses, the listener usually reacts immediately to the words of the other person. The assignment to the audio text should include the students' immediate reaction during the audition, i.e. Of course, it happens when you have to listen to a long speech and react only at the end of the conversation. But this reaction, too, tends to be a process of perception rather than a demonstration of what one has heard;

4) Speaker's attention.

The speaker usually addresses his or her speech to the interlocutor, taking into account his or her nature and intent, and often responds to his or her remarks verbally orby non-verbal means, changing or adapting their reasoning.

Of course, classroom auditing is not a real-life situation. However, in order to teach students to listen to the speech, which will prepare them for external perception, they need to know the specifics of these situations and be prepared to deal with them successfully in real life.

On the basis of the above characteristics, some recommendations (not rules) can be made for the selection of audited drafts:

- they must be represented by an informal speech (informal talk) or at least a simulation of such speech. A typical written text that is read in the classroom as an audition text will not provide learners with practical understanding of spoken discourse, conversation.

It is very important for a foreign language teacher to be able to improvise in a foreign language (although there are also disadvantages: learners hear only your voice, and very few can do it without notes or notes for themselves) [8];

- direct speaker-listener interaction (direct speaker-listener interaction). Here again, your improvisation is useful. Video is also useful effectively influences perception on hearing;

Since in life the thoughts are not lost again, to teach the students to a onetime audition. As a compromise, ask them to do everything possible after the first audition and check the results. Then allow them to listen again for further practice and better answer.

What other difficulties students may have in auditioning, where they have doubts and uncertainties and how to overcome them, we shall consider further.For both the native speaker and those studying a foreign language, it is equally difficult to derive meaning from an ambiguous message in which the speaker provides confusing information. Ambient interference, like someone talking, car noises in the street, phone calls, canas well as distraction, as well as the slurred speech or the quiet voice of the interlocutor.

In addition to external stimuli, there are internal influences and problems that negatively affect effective listening: lack of interest in the subject, negative attitude to the voice of the announcer (interlocutor) or event; fear of having to contribute to further discussion after an audition; concern about degree missing information told by the speaker. 
Lack of knowledge of the subject matter of the proposed conversation, as well as lack of a common stock of words, can lead to an incorrect listener understanding of words (e.g. flower - flour - floor; or no - know, etc.). There is a problem of "understanding each word".

Many people who learn a foreign language don't realize that when they listen to their native language, they don't actually listen to every word. Moreover, they underestimate the fact that we closely link linguistic knowledge to our (existing) experience and knowledge of themes and culture. This means that they often have some unrealistic expectations and therefore try to understand every word of audio text. Fairch and Casper point out that an absolute understanding of audio text is an erroneous representation of how the natural process of receiving information in the mother tongue occurs $[1,65]$. An effort to understand everything fails to yield effective results, causes a sense of fatigue and ultimately leads to failure.

You have to teach students to take the right information, ignoring the wrong information, especially teach them how to do it in their own language. This needs to be explained to students. It will be useful to practice sometimes tasks, for example, to listen quickly enough long text. For the sake of one or two items of information needed. The text can be split into short parts, pausing [9].

Students' concerns are compounded by the incorrect organization of assignments to the text listened to in a classroom not linked to the text or preparation to it through activation of previous knowledge (as we mentioned earlier), in other words, tasks of the type: "Listen to the text and answer the questions". This kind of mission is more of a control than a training exercise.

In order to develop a sense of confidence among students, care should be taken to create a positive experience of listening in a class. In the authors' view, this can be achieved as follows:

- Listen more both in class and on your own. Audition texts are good models for pronunciation [11]. It follows that the more students listen to audio texts, the better they not only understand foreign language speech, but also improve their pronunciation. It should always be borne in mind that successful communication depends not only on the ability to speak, but also on how well we are able to listen and understand language;

To select interesting material for the audition;

Clear objectives for the trainees;

- develop tasks both to understand the content and to involve students in the discussion process after the audition. At the same time, make it clear to the students that they will have the opportunity to discuss their answers in pairs before they speak to the whole group (to relieve fear), which will clearly help them to remove some of their doubts [10]. But the key here is for the students to first understand what it is about and then to find out what impression the content has made on them.

Thus, perhaps the most important factor in learning to listen more effectively is the confidence of the learner. And confidence can come only with practice from the earliest stage of learning. The role of the teacher is to provide learners with as much positive listening experience as possible, to give them the opportunity to feel the pleasure of understanding foreign language speech, to provide appropriate audio material in classes, to make them use of all available Internet resources; 
assign clear tasks and correct commands to listeners; develop tasks to involve students in the discussion process.

\section{REFERENCES:}

1. Faerch C., Kasper G. The role of comprehension in second language learning. Applied Linguistics. 1986. 7/3. - PP. 257-274.

2. Flowerdew J. Academic listening: Research Perspectives. Cambridge: CUP, 1994. Patsy M. Lightbown and Nina Spada. How languages are learned. Oxford: OUP, 2008. - PP. 29-49.

3. Rost M. Introducing listening. Penguin, 1994. - P. 94.

4. Rost M. Listening in language learning. Longman, 1993. - PP. 98-100.

5. Schank R. The structure of episodes in memory // Bobrow S.A., Collins D., Collins A. (eds.). Representation and Understanding: Studies in Cognitive Science. New York: Academic Press, 1975. - PP. 237-272. 1996.

6. Ur P. A course in language teaching: Practice and theory. Cambridge: CUP,

7. Бочарова Т.И. Особенности естественной речи и методическая модель обучения непринужденному общению студентов вузов // Научнопедагогическое обозрение (Pedagogical Review). 2014. Вып.

8. Елухина Н.В. Преодоление основных трудностей понимания иноязычной речи на слух как условие формирования способности устно общаться // ИЯШ. 1996. № 4. - С. 25-29.

9. Елухина Н.В. Обучение слушанию иноязычной речи // ИЯШ. 1996. - № 5. -С. 20-22.

10. Игна O.H. Обучение будущих учителей иностранного языка управлению учебной деятельностью на уроке // Научно-педагогическое обозрение (Pedagogical Review). 2013. Вып. 2 (2). - C. 36-44.

11. Михайлова O.B. Обучение профессионально-ориентированному аудированию специалистов технических вузов // Вестн. Томского гос. пед. унта (TSPU Bulletin). 2014. Вып. 9 (137). - С. 105-109.

12. Халеева И.И. Основы теории обучения пониманию иноязычной речи. М.: Высшая школа, 1989. - С. 42. 